\title{
Vestiges of the Phoenix: De Quincey, Kant and the Heavens
}

\author{
Alex Murray
}

\begin{abstract}
This essay examines the context surrounding Thomas De Quincey's 1846 essay, 'System of the Heavens as Revealed by Lord Rosse's Telescope', placing it in relation to the thesis of Robert Chambers' then anonymous proto-evolutionary Vestiges of the Natural History of Creation. I argue that De Quincey's essay - which never mentions Vestiges - can be read as an attempt to refute the 'succession' model of evolution and development put forward by Chambers, and that it does so by turning to Immanuel Kant's 'Phoenix of Nature'. The article traces the complex relationship between De Quincey and Kant's model of the Heavens through a comprehensive analysis of both Kant and astronomy in De Quincey's voluminous body of work, complicating our understanding of De Quincey's relationship to the 'destroyer' of Königsberg, and revealing the crisis of experience that emerged in De Quincey's engagement with Kant and the Heavens.
\end{abstract}

Key words: De Quincey, Kant, Chambers, Astronomy, Experience, Evolution

\section{Vestiges of the Phoenix: De Quincey, Kant and the Heavens}

Thomas De Quincey's essay of September 1846, 'System of the Heavens as Revealed by Lord Rosse's Telescope', has long been seen as one of

Victoriographies 1.2 (2011): 243-260

DOI: $10.3366 /$ vic.2011.0031

(C) Edinburgh University Press

www.eupjournals.com/vic 
his most unusual. An ostensible review of Thoughts on Some Important Points Relating to the System of the World written by the University of Glasgow Professor of Astronomy and good friend, John Pringle Nichol (1846), it contains scant information on Nichol's book, and the true object of the essay is difficult to pin down. On one level, it is a work of speculative philosophy that is concerned with the particular problems of Kantian metaphysics; on another, it is a whimsical account of the Glasgow Observatory, a translation of Jean Paul Richter, and much else besides. For John Barrell, its famous description of the Nebula of Orion is the most 'disturbing instance of double vision' in De Quincey's writing, testament to the psychological trauma that haunted De Quincey's work (Barrell 105). It has also been noted by Jonathan Smith and Robert Platzner as providing an exemplary instance of De Quincey's engagement with Astronomy and Kant respectively. While De Quincey is not known for being either a thorough or systematic thinker, I would like to extend Platzner's and Smith's work by tracing two notable absences from the essay. The first, given the time of publication, is the most glaring: no explicit reference to Robert Chambers' then anonymous Vestiges of the Natural History of Creation (1844). The second is less notable, but hardly less important: the absence in the published version of direct reference to Kant's relatively obscure work of 1755, Allgemeine Natter geschickte und Theorie des Himmels, Universal History of Nature and Theory of the Heavens. There is evidence that De Quincey was familiar with both works, yet neither appear here. In tracing the absence of both texts, an absence filled with meaning, I will sketch the larger question of De Quincey's relationship to Kant and to scientific knowledge, mapping out the consequences for De Quincey of transcendental idealism which illuminates the 'System of the Heavens'. In the horror of gazing on the Nebular of Orion, De Quincey sees the logic of Kant's critical project writ large, and, with it, a crisis of both religious faith and of the subject. In tracing the figure of the 'phoenix of nature' I argue that De Quincey's attempt to reject models of 'evolutionary' theory - in particular the logic of succession such as Chambers' -, leads him back to endorsing Kant's early work on Newtonian physics.

\section{De Quincey and Vestiges of the Natural History of Creation}

Victorian Science has increasingly become an important sub-field in the study of Victorian literature, with many critics paying attention to the ways in which developments in natural history in particular can be read through many canonical writers of the day (Hardy, 
Eliot, Tennyson). The attention, particularly over the past few years, has understandably centred on Darwin and his associates. However, James A. Secord's Victorian Sensation: The Extraordinary Publication, Reception and Secret Authorship of Vestiges of the Natural History of Creation, has expanded our knowledge of those pre-Darwinian debates over evolution, presenting the publication and reception of Robert Chambers' book as a major intellectual event of the period. With its compelling narrative of human evolution and accessible summarising of complex scientific material, it was read widely amongst the intellectual upper middle classes and the lower middle classes throughout the Victorian period. Approximately 30,000 copies were sold in twelve editions between its initial publication in October 1844, and the edition of 1884 revealed Chambers as the author. Many of the great literary and intellectual figures of the day, such as Tennyson, Disraeli, Abraham Lincoln and Elizabeth Barrett Browning, record in private correspondence the sensation and confusion that its publication caused as the implications of its insights became apparent.

De Quincey certainly knew Robert Chambers, the author of Vestiges of the Natural History of Creation, although there is some uncertainty as to the extent of their acquaintance. They were both close friends of J.P. Nichol, one of the few people to whom Chambers openly acknowledged he was the author (Secord 466-7). David Masson lists Robert Chambers as one of De Quincey's regular visitors in his later years, and there is a reference to De Quincey in Chambers' edited miscellany, A Book of Days (Massson 24; Chambers 671). Moreover, through James A. Secord's research we have a clear picture of the extent to which debates over the book saturated literary circles in the 1840s, and it would seem impossible that De Quincey, as an active member of Edinburgh's literary class, would not have read it, or at least accounts of it in the press, as well as been privy to the open secret of Chamber's authorship. For instance, a review of Explanations, Chambers' defence of Vestiges, was published in the same February 1846 edition of Tait's Edinburgh Magazine as De Quincey's 'The Antigone of Sophocles'. So, if we can speculate that De Quincey had read Vestiges, or at least knew of its major thesis, why did he not mention it in his review of Nichol written only two years after its publication? This is of course an unanswerable question, yet in what follows I would like to identify some uncanny echoes between 'System' and Vestiges, along with its 'defence' Explanations, published in December 1845 . My contention is that, in covering exactly the same ground (the nebular hypotheses and its recent refutation through the discoveries revealed by Lord Rosse's telescope), we can map an esoteric 
critique of the logic underpinning Chambers' book in De Quincey's essay. Moreover, it will lay the foundations for a more considered understanding of De Quincey's shifting response to Kant's Cosmology and the terror produced by Lord Rosse's telescope.

Chambers' book is an attempt to marry the natural sciences with the history of creation. At each point in the narrative, a speculation on the idea of creation is married with the latest observation in science. The result is a plausible attempt to draw on contemporary science to produce a narrative of all life in the universe. From astronomy, through geology, biology, anthropology, and theology, Chambers synthesises evidence to provide a model for the law of development. The attempt to unite disparate disciplines of empirical observation together under one speculative idea led to a great deal of hostility. The most obvious criticism, and the greatest danger of Chambers' method, was that it called into question the story of Genesis. Yet Chambers attempts to side-step this by suggesting he was trying to 'give the true view of the history of nature, with as little disturbance as possible to existing beliefs', and to remind the reader that, for instance, 'Geology at first seems inconsistent with the authority of the Mosaic record', but, in time, will become reconciled to it (Vestiges 388-9). De Quincey rejects such a claim in 'System of the Heavens': 'the Mosaic cosmogony, indeed, gibes the succession of natural births; and that succession will be more and more confirmed and illustrated as geology advances' (Works XV, 420). Yet the claims of Chambers struggle to map onto the temporal claims of Genesis, and De Quincey suggests that there is no way in which the scriptures should 'condescend to human curiosity' (Works XV, 420). Any attempt to reconcile the time of revelation with the successive time of the material world was futile.

It was, however, not the theological terrain on which De Quincey was to attack the evolutionary model of revelation, but on the very scientific grounds of its use of astronomy. Chambers' Vestiges begins with an account of the nebular hypotheses developed by the Hershchels, who had argued that the nebulae were formed of gassy liquids: 'they have found within the limits of our astral system, and generally in its outer fields, a great number of objects which, from their foggy appearance, are called nebulae; some of vast and irregular figure, as that in the sword of Orion, which is visible to the naked eye' $(7-8)$. The theory stated that the solar system was once incandescent gas that cooled into rings and broke off to form planets. These objects of 'foggy appearance' were then nebulae that were cooling and condensing into planets, yet, if they could be viewed properly, would be shown not to be gasses but objects in a process of contraction. 
These nebulae, if proven to exist, demonstrate that the universe is not composed of static objects, but is instead in a process of evolution as the nebulae gathered together to form solar systems and planets beyond our own. The inference of this, of course, would be that the narrative of Divine Creation was impossible and that the Universe modulated and shifted according to its own natural process of creation.

The nebular hypothesis, central for Chambers in Vestiges in 1844, was called into question once the observations of Lord Rosse's telescope had been taken into account. Rosse's extraordinarily powerful telescope, otherwise known as the Leviathan of Parsonstown, began, in February 1845, to examine the nebulae in more detail than ever before. In an experiment of December 1845, the telescope resolved the nebulae, proving that, when observed fully, it did not contract into objects but remained as gas. The inference, therefore, was that the universe did not in actuality follow its own rules, but was underpinned by some sort of chaos, and that it was infinite in both time and space. In short, Rosse's telescope had managed to call into question the Newtonian mechanistic view of cosmology that suggested it had to work towards certain a priori principles. De Quincey was, however, rebuked by J.P. Nichol for having misunderstood Thoughts Relating to the System of the World, the subject of the essay. Indeed, as Jonathan Smith has noted, De Quincey's infamous anthropomorphised description of the Orion Nebular was made from a plate by Sir John Herschel included in Nichol's earlier book, Views of the Architecture of the Heavens, and not from any observations made through Lord Rosse's telescope (Smith 205). In fact, even a brief examination of the sketches in Thoughts Relating to the System of the World show them in a clear state of resolution and not contraction(Nichol Thoughts, 20; 21). It seems De Quincey maintained that image for a certain effect of terror at the mysteries of the infinity of space that become the central theme of the essay.

If Nichol's Thoughts and Lord Rosse's telescope had 'smashed' the Nebulae Hypothesis, they had called into question the empirical observations that had been used to shore up Chamber's book. Most importantly, a scientific rejection of the first section, 'The Bodies of Space', had dinted the mechanistic logic that underpinned the book. Chambers wanted to outline the limits of a system - from the cosmological to the subjective - and if one part of it fell apart, the rest must inevitably follow. The attempt to narrativise a mechanistic, scientific view of the world had made it necessarily linear. However, if the opening of the story could be demonstrated as false, it would 
undermine the entire account. Safe in the destruction of the scientific basis for the Nebulae Hypothesis, De Quincey can also turn to attack any philosophical or theological authority that one could imbue into that system. His basic contention in the final section of 'System' is that there is a philosophical error in granting a revelatory power to astronomy or geology. The only form of revelation from the heavens is the 'special light' that enables man to reveal what would otherwise 'remain sealed in darkness' (Works XV, 420). Astronomy and Geology are therefore confusing human experience with transcendental knowledge, that knowledge of 'true religion' which is not of this world. The attempt to posit a priori forms of knowledge to be confirmed by experience is to denigrate both. Yet, as we shall see below, De Quincey was well aware that the philosophical logic of Kant had hardly been 'smashed' by the proofs of Lord Rosse's telescope. In what follows, I highlight another, more unspeakable terror that lies at the heart of the essay; the terror of Kant's critical project being realised. The Nebular Hypothesis is not really what is at stake in De Quincey's essay, or not in the way it may appear. While it may seem as if De Quincey was taking some sort of glee in the refutation of the mechanic La Placean view of the Universe, he was instead troubled by something far more profound, that of the idea of the universe as a phoenix. The chaos that exists at the outer edges of the universe, the infinite reaches of time and space, do not, as De Quincey knows, wholly refute the mechanistic image of the universe, but instead endorse it. In rejecting the logic of the astronomical and geological bases for a model of successive time, De Quincey had forced himself to adhere to the Kantian model of the phoenix of nature, a different, yet still mechanistic vision of the universe that he would earlier support, but later attempt to refute.

\section{De Quincey and Kant}

De Quincey's relation to Kant has always been a contested topic for critics. He was originally enamoured with Kantian idealism, but gradually began to develop more and more antipathy to it, before returning to praise elements of Kantian morality close to his death. His works from the 1820 s demonstrate a commitment to having Kant's work properly received in England. Those essays in the Westmoreland Gazette are almost wholly supportive of Kant's work, while 'Letters to a Young Man Whose Education has Been Neglected' (1823) attempts to rectify the misreading of Kant in English, with De Quincey stating: 'I should liberate the name and reputation of Kantean [sic] philosophy 
from any delusions which may collect about its purposes and pretensions, through the representation of those who have spoken it amongst ourselves' (Works III, 86). De Quincey's mission to rescue Kant from poor interpretation has, however, not been met with general appreciation by those who have evaluated De Quincey's role as an importer and champion of Kant's work in England. Rosemary Ashton, for instance, has suggested that De Quincey, in particular when contrasted to Coleridge, 'remained vague and ill-informed about Kant' (Ashton 42). Ashton is here repeating a critical commonplace that had developed over the course of the twentieth century. The main proponent was René Wellek, the Czech-American scholar, whose corrosive analysis of De Quincey in Kant in England (1931) has proved dominant. In it, he suggests that De Quincey's Kant was confused, with moments of accurate insight, others of staggering ignorance. In ten pages, Wellek provides a portrait of De Quincey as the opportunistic reader, not a philosopher. As he states: 'De Quincey is one of the few writers who claim a personal experience with Kant. But this experience was based on a gross misunderstanding of the purpose of Kantian philosophy and even if we could grant the right to misunderstand Kant, we feel that this experience, however actual and indisputable, remained only skin-deep, the expression of a mood, of a moment's despair and tedium' (Wellek 181). It has been difficult to rescue De Quincey's Kant from this scathing attack, but Grevel Lindop has argued that the relationship was far more nuanced, and that De Quincey had begun very much enamoured with Kant's system of thought, before ultimately rejecting it as 'the idea that space and time, causation, even logic itself might all be properties of human consciousness with no basis in external reality was one which he found terrifying to confront'(Lindop 132). In more recent studies, such as Paul Youngquist's, there has been a move to understand the relation in a more complex fashion by tracing a dialogue with Kant beyond the small number of explicit references. Youngquist's rereading of The Confessions through De Quincey's embodied understanding of health and digestion has opened up the material De Quincey of bodily experience as a response to the 'Kantian analytics of the beautiful and sublime'(Youngquist 119). De Quincey's own misreading of Kant's accuracy have also been explored by Daniel Sanjiv Roberts, extending our understanding of the ways in which De Quincey appropriates Kant. The general critical account seems to be that De Quincey found a problem with the Kantian distinction between a priori knowledge and a posteriori experience, and chose to reject consciousness that wasn't intrinsically tied to human experience. 
Many of De Quincey's crises of experience are products of the attempt to move through the philosophical and subjective implications of this shift, his attempt to retain experience once having rejected transcendental reason (not the transcendent truth of revelation), yet still feeling its after-effects.

De Quincey's most pronounced attack on the Kantian system comes in an instalment of 'Autobiography of an English Opium-Eater', first published in Tait's Magazine, June 1836. This sustained assault is based, ultimately, upon the philosophical despair that Kant's rejection of objective knowledge brought to the world:

As often as I looked into his works, I exclaimed in my heart, with the widowed queen of Carthage, using her words in an altered application - 'quaesiuitlucem-ingemuitquerepertâ. (Works X, 178)

The Latin here is a quote, or partial quote, from book IV of Virgil's Aeneid and the scene of the death of Dido, translated as 'her eyes searched for the light - she moaned when they found it' (Virgil 99). There is, however, a word missing in De Quincey's 'altered application' - coelo, the heavens. Of course it was necessary to remove the location of the gaze for the allusion to make sense. But this removal can give us pause to speculate about the unusual relationship between Kant, De Quincey, and the Heavens. In abjuring Kant's speculative metaphysics, what exactly does De Quincey say of his physics, of Kant's own extensive studies of the Heavens and his Newtonian foundations? The light that emanates from Kant's work, leading to De Quincey's groan, one may consider the false illumination of reason. Yet, in what follows, I argue that the light from Kant's work becomes transformed in 'System' into the light that emanates from the funeral pyre of the phoenix of nature.

\section{De Quincey and Kant on the Cosmos}

The beginning of 'Systems of the Heavens' starts with reference to De Quincey's own translation of Kant's short essay 'Die frage, ob die Erdeverlate, physicalischerwogen' from 1754, in De Quincey's translation 'Age of the Earth'. This was a very early work of Kant, as was the majority of his writing on astronomy, and precedes the critical project by some decades. De Quincey's reference to it dominates his engagement with Kant in 'Systems', in which he humorously admonishes Kant for an inappropriate question to be put to our female planet. Comedy aside, De Quincey's main points of contention seem to be: firstly, that Kant mistook the mathematical foundations for 
grasping the age of our fellow planet, Jupiter, and, secondly, that, in not grasping the planetary structure, Kant had failed to realise that the earth was full of youthful vigor. The criticism is circuitous - Kant was too busy trying to systematise a means of ascertaining the age of the planets to see evidence of growth and expansion in the present: that the spread of science and technology are indicative of a planet not in an era of decay, standing on its last legs, uttering an exhausted 'fin du globe', but, on the contrary, that entering a period of unparalleled growth. As De Quincey triumphantly states:

Is it likely, is it plausible, that our Earth should just begin to find out effective methods of traversing land and sea, when she had a summons to leave both? Is it not, on the contrary, a clear presumption that the great career of earthly nations is but on the point of opening, that life is but just beginning to kindle, when the great obstacles to effectual locomotion, and therefore to extensive human intercourse, are first of all beginning to give way? Secondly, I ask peremptorily, - Does it stand with good sense, is it reasonable that Earth is waning, science drooping, man looking downward, precisely in that epoch when, first of all, man's eye is arming itself for looking effectively into the mighty depths of space? A new era for the human intellect, upon a path that lies amongst its most aspiring, is promised, is inaugurated, by Lord Rosse's almost awful telescope. (Works XV, 400)

De Quincey's enthusiasm here is, of course, only rhetorical, and it is revealed only too soon that Lord Rosse's telescope provides us with an abject horror rather than any triumphalism. We could tellingly compare this passage to the beginning of Suspiria de Profundis, published 18 months earlier in Blackwood's Edinburgh Magazine (part I published in March), in which De Quincey frames the technological trappings of modernity as destructive of something like a spiritual experience of the contemplative 'grandeur which is latent in all men', and that this destruction must be met by 'forces in the direction of religion or profound philosophy, that shall radiate centrifugally against this storm of life so perilously centripetal towards the vortex of the merely human' (Works XV, 130). Kant's 'Transcendental Doctrine of Judgment' posited itself as an Island against the illusory nature of experience - 'the homeland of truth' against 'the wide and stormy ocean, the true home of illusion' (Kant Critique 257). Yet, for De Quincey, it would seem that it was the illusory nature of transcendental judgment itself that led to an inability to understand the crisis bequeathed to modern man by that very real storm of experience. It seems that, for him, the transcendental was incapable of providing a buffer to real experience, denying us instead those 
forms of spiritual or philosophical contemplation that could make sense of the infinite horror of true experience.

Robert Platzner argues that what we see in 'System of the Heavens' is something akin to a 'post-Kantian' sublime in which the experience of staring into Rosse's telescope is inherently destructive:

within this system of self-inflicted persecutions one cannot turn towards the heavens or the phenomenal world at all in hopes of tranquil restoration. Instead, there is only a post-Kantian "turn" toward a radicalized sensibility in which the intense feelings aroused by peering into the Universe through Lord Rosse's telescope return to consciousness itself, unable to connect, cognitively or affectively, with the object world. The rhetoric of sublimity has nothing to adhere to in a universe in which the imagination moves from "infinite to infinite"; indeed once the very sense of magnitude has imploded under the weight of a feeling for infinity, it is no longer possible to encode things or to incorporate them into a system of renovative reflections. (Platzner 205)

In what follows I will extend Platzner's reading, suggesting it was the particular effect transcendental idealism has on experience that so terrified De Quincey, as it took away both the transformative potential of experience - as well as the 'renovative reflections' that allow us to deal with it.

Kant's Newtonian legacy is, I would suggest, underpinning De Quincey's rejection of Kant's thesis on the age of the earth and his understanding of space more generally. References to Kant's Natural History of the Heavens are scattered throughout De Quincey's writing, from his early editorials in the Westmoreland Gazette onwards. These present, in microcosm, De Quincey's shifting relationship with the Kantian system. The first instance from September 1819 in the Gazette article 'Immanuel Kant \& Dr Herschel' is a glowing endorsement of the Kantian a priori:

[t]wenty-six years at least before Dr Herschel discovered the planet which bears this name (otherwise called the planet Uranus, and in England the Georgian planet), it had been predicted - or, to speak more truly, it had been demonstrated - by Kant that a planet would be found in that region of the heavens ... Herschel's was made empirically, or a posteriori by means of a fine telescope: Kant's scientifically or a priori as a deduction from certain laws which he has established in his Celestial System (Himmel's System). (Works I, 167-8)

In August 1830, De Quincey published an essay in Blackwood's Magazine entitled 'Kant in His Miscelleaneous Essays'. In it, he laments the 
lack of space available and claims he would have written an essay entitled 'The Natural History of the Heavens', in which Kant anticipated much of Herschel's views on the system of the Universe (Works VII, 78). In the removed note on Kant from 'System of the Heavens' De Quincey states: 'Kant, by his "Natural History of the Heavens", by his elaborate and polemic essay on the "Living Forces", and by other contributions to mathematical physics, had been obliged to dip into contemporary mathematics' (Works XV, 626). So it is indubitable that De Quincey knew Kant's early work, rather thoroughly if we take him at his word and the stretch of references over a 25 year period. Yet it is not a simple matter that De Quincey had taken on board Kant's early ideas; he is far too deliberate for that. Instead, I would like to suggest that De Quincey's 'System of the Heavens', can be re-read as a critical engagement with Kant's early cosmological writing, and, in particular, the figure of the phoenix. ${ }^{1}$

\section{Tracing the Phoenix}

If we recall above, De Quincey quoted Virgil on the death of Dido to express his antipathy towards the Kantian system - gazing into the heavens, seeking the light, he moaned when he found it. Dido, Queen of Carthage, was Phoenician in background, and twice in the Aenied is referred to as 'Phoenissa', which Ahl translates as 'descendent of Phoenix' (Virgil 26, 93). It is only coincidental, perhaps, but it was to be, in 'System', the Phoenix of Nature that De Quincey finds when he gazes into the Kantian Heavens. When lambasting Kant's process for approximating the age of the Earth, De Quincey happens on another possibility:

But suddenly at this point a demur arises upon the total question. Kant's very problem explodes, bursts, as poison in Venetian wine glass of old shivered the glass into fragments ; for is there, after all, any stationary meaning in the question ? Perhaps, in reality, the earth is both young and old. Young - if she is not young at present, perhaps she will be so in future. Old - if she is not old at this moment, perhaps she has been old, and has a fair chance of becoming so again. In fact, she is a phoenix that is known to have secret processes for rebuilding herself out of her own ashes. Little doubt there is but she has seen many a birth-day, many a funeral night, and many a morning of resurrection.... She recasts her glorious habitations in decomposing them; she lies down for death, which perhaps a thousand times she has suffered; she rises for a new birth, which perhaps for the thousandth 


\section{Victoriographies}

time has glorified her disc. Hers is the wedding garment, hers is the shroud, that eternally is being woven in the loom. And God imposes upon her the awful necessity of working for ever at her own grave, yet of listening for ever to his far-off trumpet of 'palingenesis'.

(Works XV, 397)

This passage should be compared with the following, from Chapter Seven of Kant's Universal History of Nature:

The Phoenix of Nature burns itself up only to return from its ashes, come back to life and be young again. If we now follow the Phoenix through all infinity of time and space, and if we see how Nature, even in the aspect of decay and obsolescence, still has the power for new creations; if we see how, at the other edge of creation and in the realm of unformed, raw matter, Nature proceeds with steady steps toward the expansion of the plan of Divine unfolding and fills all space and time with its miracles - if we see all this, then the mind, pondering such vistas, will sink into deep wonder. Yet the mind is discontent with this grandiose object whose transience can never appease the soul, and wishes to get back to that very being up close whose understanding and grandeur are the light source shining through the whole nature as from a centre. ('Creation' 410-11).

The proximity here between the two statements is too close to be coincidental. In effect, Kant and De Quincey are using the same metaphor to deal with the same problem to approximate two very different solutions. For Kant, the question is how to negotiate between the idea of transcendental knowledge - that the Universe recreates infinitely - with empirical knowledge, what we can know of nature. As De Quiney well knew, the 'solution' to this great dilemma would be the very essence of Kant's critical project. De Quincey will instead use the image of the phoenix to dramatise the isolation - the horror - that results from an attempt to draw together transcendental reason and empirical experience at the cost of Divine Revelation. In believing that we have a knowledge of the infinity of creation through scientific reason, we allow ourselves to enter into a position whereby the infinite expanse of time and space leaves us feeling adrift in the universe, forced to listen to the eternal lament of palingenesis. In short, Divine Revelation is, for De Quincey, a transcendental anchor, a grounding mechanism that allows us to make sense of experience. Cast free from that into a process of endless reflection we end up with a horror of the phoenix, at the mercy of the infinite regresses of time and space, destined to repeat ad infinitum the resurrection without revelation. 
The phoenix is a fire bird that has a clear relation to the mythic firebirds of Indian, Syrian, Chinese, Egyptian, and Greek mythology; yet, as early as 100 A.D., Clement of Rome took the mythic bird as evidence for the resurrection (Van Den Brock 2-7). The most wellknown early definition comes from Isidore of Seville (560-636), who, in his Etymologies, described it as:

a bird of Arabia, so called because it possesses a scarlet (phoeniceus) color, or because it is singular and unique in the entire world, for the Arabs say phoenix for "singular." This bird lives more than five hundred years, and when it sees that it has grown old it constructs a funeral pile for itself of aromatic twigs it has collected, and, turned to the rays of the sun, with a beating of its wings it deliberately kindles a fire for itself, and thus it rises again from its own ashes'. (265)

It is thus a metaphor for resurrection, but, importantly, without revelation.

The phoenix appears, to my knowledge, on three other occasions in De Quincey's body of work. Once, as a rather amusing metaphor for the human appetite in 'Dinner, Real and Reputed', another in the essay 'On War', and, finally, in the concluding section of 'Suspiria De Profundis' entitled 'The Palimpsest' - which is of importance here in confirming its meaning for him as a mechanical image of blind resurrection. Within that essay, De Quincey is lamenting the ways in which we have attempted to distort the model of the palimpsest for understanding the mind: as we have sought to preserve print rather than allow textual accretion - layers of texts on a single piece of parchment - over a long period, we now deny the complexities and contours of mental life. De Quincey then sees the phoenix - a mechanical, secular, solitary symbol - as adequate to explain the nature of modernity:

Even the fable of the Phoenix, that secular bird, who propagated his solitary existence, and his solitary births, along the line of centuries, through eternal relays of funeral mists, is but a type of what we have done with Palimpsests. We have backed upon each phoenix in the long regressus, and forced him to expose his ancestral phoenix, sleeping in the ashes below his own ashes. (Works XV, 157)

It is crucial here to note that the phoenix is 'secular'. The word is usually understood, in common modern usage, through an opposition to the religious: here the Latin root scul-um is read as pertaining to 'the world' or 'this world' as opposed to the divine world of heaven. Yet it also meant in Latin 'generation' or 'age', and De Quincey here is 
referring to this meaning of the term, which he takes from Milton's Samson Agonistes:

So Virtue, given for lost,

Depressed and overthrown, as seemed,

Like that self-begotten bird,

In the Arabian woods embost,

That no second knows nor third,

And lay erewhile a holocaust

From out her ashy womb now teemed,

Revives, reflourishes, then vigorous most

When most unactive deemed;

And, though her body die, her fame survives,

A secular bird, ages of lives. (1.1689-98)

Samson Agonistes, and, in particular, the image of the phoenix, have long been a topic of debate in Milton studies. Whether one chooses to read it as an image of Christian redemption from the book of Job, or a pagan/secular threat to that very idea, it is an image on which interpretations of the 'Dramatic Poem' rest. (See Budick.) De Quincey's version here, and in 'System', is playing on that very tension between the Christian revelation of God in the form of redemption, and its scientific denial through the idea of the phoenix as the undead, that which is marked by accretions, development, according to the laws of nature. Kant's phoenix is one of transcendental reason, which De Quincey's pits against transcendental revelation.

Kant's idea of the phoenix-like nature of the earth can also clearly provide us with links back to the proto-evolutionary Vestiges of the Natural History of Creation. If the Universe, and the earth along with it, undergo repeated destruction and resurrection, it mirrors very closely the arguments mounted by Chambers in his 'defense' of Vestiges, Explanations. Chambers had claimed that Vestiges celebrated rather than diminished the mysteries of divinity, as it increased through its analysis: " $\mathrm{t}]$ hat great Being, who shall say where is his dwelling-place, or what his history! Man pauses breathless at the contemplation of a subject so much above his finite faculties, and only can wonder and adore!' (26). Chambers went on in Explanations to clarify that he was not suggesting a new theory of 'animate nature', but a working out of the 'LAW' of revelation (3). The basic proposition is that there is a system of revelation and it is only now, with the advances in natural science, that we can grasp the precise manifestations of this law. The transcendental 'LAW' of revelation is, in Explanations, confirmed in 
what is seen through Lord Rosse's telescope. The experiments of 1845 had arguably challenged Chambers' hypothesis, yet, in Explanations, he rejects this, stating that the resolution was 'expected' and was of 'no consequence' to the nebular hypothesis (9). This was precisely because the a priori natural law that Chambers had constructed could account for all phenomena: ' $[\mathrm{t}]$ he wondrous masses which people the Mighty Void are under the control of natural law. The workings of the little world of the human mind - the opposite extreme of the system - are under law likewise. We have thus the character of the limits of the system fixed' (26, italics in original). Chambers here is fundamentally Kantian in his attempt to sketch out a critical idealism in which a scientific model could account for all. It is perhaps the importation of this sort of scientism that De Quincey finds so objectionable. Equally objectionable for De Quincey was any assertion of an infinite system and structure of eternal return that underpinned the evolutionary narrative as Chambers conceived it. The conclusion of Explanations provides a striking image of temporal and spatial infinite repetition: '[t]he vital flame that proceeded from him [God, the 'Eternal Author'] at first returns to him in our reflected form at last, bearing with it all good and lovely things, and making of all the far-extending Past but one intense Present, glorious and everlasting' (188). The everlasting present which concludes Explanations is another iteration of the phoenix, the eternal recurrence of a system which contains no outside.

It is worth considering how singular De Quincey's views were of Kant's critical project. While there had long been veiled accusations that Kant's system could lead to atheism, De Quincey had, on numerous occasions, suggested that Kant was 'the destroyer' of Christian hope, and his thought must be rejected accordingly. His attack in his 1834 article in Tait's Magazine on Samuel Taylor Coleridge can stand in as indicative: 'he had no instincts of creation or restoration within his Apollyon mind; for he had no love, no faith, no self-distrust, no humility ... he exulted in the prospect of absolute and ultimate annihilation' (Works X, 299). This attack, while not De Quincey's most vituperative, did not pass without comment, and was the object of an article of rebuke from his friend Nichol in the Glasgow University Album of 1854. As De Quincey was preparing his collected works for publication, Nichol thought that this denunciation of Kant was too intemperate and likely to cause De Quincey some embarrassment, or harm his future reputation. The short article is a passionate defense not just of Kant, but of intellectual endeavour more generally. Nichol argues that De Quincey has, in labelling 
Kant effectively an atheist, accused him of insincerity in more than half of his body of work, dealing with morals, ethics, practical reason, and religion. Nichol wants De Quincey to provide evidence that this is indeed the case, and seems to suggest that De Quincey is content to devalue German metaphysics over 'some Scottish preserve' - most likely the empiricism of the Scottish Enlightenment ('Mr De Quincey' 261). Of course, De Quincey can't be aligned with the thought of Hume and others in his circle, of whom he was also critical. Yet Nichol's meaning is clear: De Quincey wants to retain an idea of 'experience' rather than accept the a priori of the 'Speculative Faculty'.

\section{Conclusion: the idea of Experience}

What is at stake here, then, is the problem of experience. Kant's understanding of the cosmology and its infinite nature through the figure of the phoenix could never have been 'experienced' prior to the arrival of Lord Rosse's telescope. Kant's earlier suggestion that the earth was infinitely destructible and resurrectable is confirmed by the technologisation of experience. For De Quincey, the advent of an empirical confirmation of a principal transcendental is a confirmation of that system itself. So De Quincey's admonishing of Kant must be read in this light. De Quincey's project is one designed to save experience and those forms of philosophical contemplation that could account for them, a project which becomes increasingly at odds with Kant. If, as Stanley Cavell has suggested, Romanticism can be read as a monitoring of, and particularly dissatisfaction with, the Kantian settlement, then De Quincey's attempt to redeem experience is exemplary of such dissatisfaction (Cavell 31). The Italian philosopher Giorgio Agamben identifies modernity as characterised by the destruction of experience. For Agamben, it was the distinction between 'the I think, a transcendental subject which cannot be given substance or psychologized in any way, and the psychological consciousness of the empirical I' that Kant bequeathed to modern experience (32). For Agamben, Kant had to posit the I that knows as transcendental, unaffected by the I that experiences. The result is that experience becomes expropriated from the self, or at least those forms of knowledge that can grasp and make sense of experience. In 'System of the Heavens', it is the empirical subject of experience gazing up into the truth of the transcendental subject, the phoenix of nature, that is filled with horror, a horror all the more real because the two modes of thought can never be brought together again. 


\section{Vestiges of the Phoenix: De Quincey and Kant}

The subject is always destined to suffer the torturous sounds of the "'far-off trumpet of "palingenesis"”, never again to find a transcendental revelation in which to ground an experience of this world (Works XV, 397).

\section{Note}

1. Robert Lance Snyder has too noticed the unspoken place of Allgemeine Natter geschickte und Theorie des Himmels in the opening pages of 'System of the Heavens', although he doesn't explore in any more detail Kant's own Newtonian position in relation to the essay. See Snyder.

\section{Works Cited}

Agamben, Giorgio. Infancy and History: An Essay on the Destruction of Experience. Trans Liz Heron. London: Verso, 1993.

Ashton, Rosemary, The German Idea: Four English Writers and the Reception of German Thought [1980]. London: Libris, 1994.

Barrell, John. The Infection of Thomas De Quincey: A Psychopathology of Imperialism. New Haven: Yale University Press, 1991.

Budick, Sanford. 'Milton's Joban Phoenix in Samson Agonistes'. Early Modern Literary Studies 11.2 (September, 2005): 1-15.

Cavell, Stanley. In Quest of the Ordinary: Lines of Scepticism and Romanticism. Chicago: University of Chicago Press, 1988.

Chambers, Robert. Vestiges of the Natural History of Creation and Other Evolutionary Writings. James A Secord (ed.). Chicago: University of Chicago Press, 1994.

- (ed.), The Book of Days: A Miscellany of Popular Antiques in Connection with the Calendar Including Anecdote, Biography and History, Curiosities of Literature, and Oddities of Human Life and Character. Edinburgh: W\&R Chambers, 1864.

De Quincey, Thomas. The Works of Thomas De Quincey, 21 Volumes. Grevel Lindop, general editor. London: Pickering and Chatto, 2003.

Isidore of Seville. The Etymologies of Isidore of Seville. Trans. Stephen Barney, W.J. Lewis, J.A. Beach and Oliver Berghof. Cambridge: Cambridge University Press, 2006.

Kant, Immanuel. Critique of Pure Reason. Trans. Norman Kemp. New York: McMillan, 1965

—. 'On Creation in the Total Extent of its Infinity in Both Space and Time' Trans Martin Schönfeld. Collapse: Philosophical Research and Development V (2009): 379-414.

Lindop, Grevel. The Opium Eater: a life of Thomas De Quincey. Oxford: OUP, 1985.

Masson, David. De Quincey. London: Macmillan, 1902.

Milton, John. 'Samson Agonistes' in The Complete Works of John Milton: Volume II, the 1671 Poems. Ed Laura Lunger Knoppers. Oxford: Oxford University Press, 2008.

Nichol, John Pringle. Thoughts on Some important Points Relating to the System of the World. Edinburgh: William Tait, 1846.

_. 'Mr de Quincey versus Immanuel Kant' reproduced in De Quincey Memorials, V II. Ed. A.H. Japp. London: William Heinemann, 1891.

Platzner, Robert. "Persecutions of the Infinite": De Quincey's "System of the Heavens as Revealed by Lord Rosse's Telescopes" as an Inquiry into the Sublime' Sensibility in Transformation: Creative Resistance to Sentiment from the Augustans to the Romantics. Ed. Sydney McMillen Conger. Rutherford: Fairleigh Dickinson University Press, 1990. 


\section{Victoriographies}

Roberts, Daniel Sanjiv. Revisionary Gleam: De Quincey, Coleridge and the High Romantic Argument. Liverpool: Liverpool University Press, 2000.

Secord, James A. Victorian Sensation: The Extraordinary Publication, Reception and Secret Authorship of Vestiges of the Natural History of Creation. Chicago: University of Chicago Press, 2003.

Smith, Jonathan. 'De Quincey's Revisions to "The System of the Heavens"' Victorian Periodicals Review, 26. 4 (Winter, 1993): 203-212.

Snyder, Robert Lance. “The Loom of Palingenesis”: De Quincey's Cosmology in System of the Heavens'. In Thomas De Quincey: Bicentenary Studies. Ed. Robert Lance Snyder. Norman: University of Oklahoma Press, 1985.

Van Den Broek, R. The Myth of the Phoenix According to Classical and Early Christian Traditions. Leiden, Brill, 1972.

Virgil. Aeneid. Trans. Frederick Ahl. Oxford: Oxford University Press, 2007.

Wellek, René. Immanuel Kant in England, 1793-1838. Princeton: Princeton University Press, 1931.

Youngquist, Paul. Monstrosities: Bodies and British Romanticism. Minneapolis: University of Minnesota Press, 2003. 